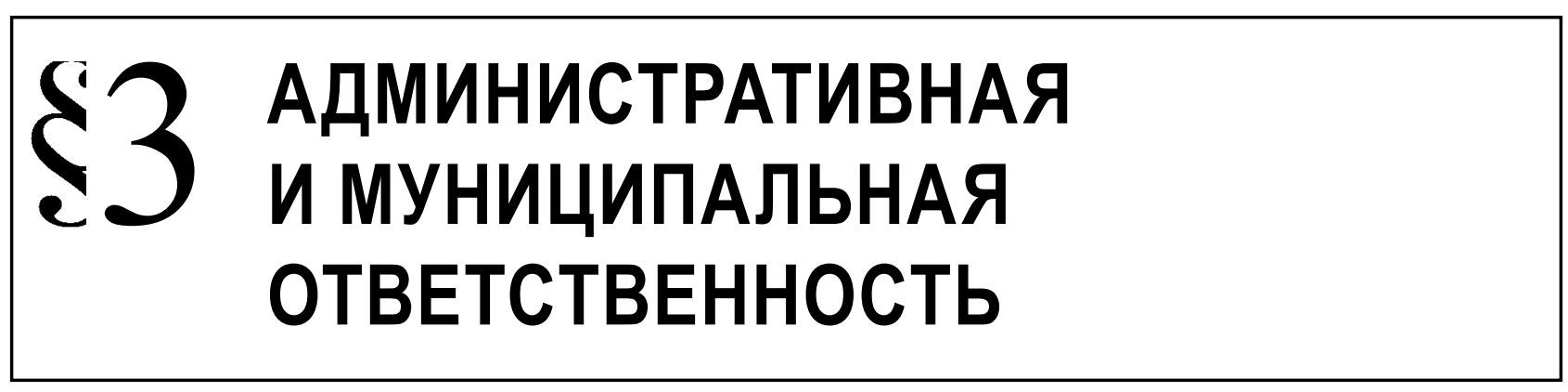

Логинова Е.С.

\title{
НАДЛЕЖАЩЕЕ ИЗВЕЩЕНИЕ В ПРОИЗВОДСТВЕ ПО ДЕЛАМ ОБ АДМИНИСТРАТИВНЫХ ПРАВОНАРУШЕНИЯХ
}

\begin{abstract}
Аннотация: Одним из способов обеспечения законности в производстве по делам об административных правонарушениях является обязанность по извещению лица, которому вменяется совершение правонарушения. Факт ненадлежащего извещения является безусловным основанием для отмены постановления о назначении административного наказания. Процессуальное законодательство непоследовательно регулирует данный институт, следствием чего является множество проблем в правоприменительной практике. В статье анализируются законодательно установленные и выработанные в правоприменительной практике критерии надлежащего извещения в производстве по делам об административных правонарушениях При проведении исследования и подготовке материала применены общенаучные методы (метод анализа и моделирования) и специальные (сравнительно-правовой и технико-юридический) В результате проведенного анализа правоприменительной практики выявлены проблемы, возникающие при извещении лии, допустивших нарушение норм действующего законодательства. Одной из основных проблем является уклонение лица, которому адресовано извещение, от его получения, и отсутствие в действующем законодательстве алгоритма действий должностных лиц административных органов в такой ситуации. В статье на основании анализа судебной практики предложен возможный вариант решения данной проблемы.

ключевые слова: надлежащее извещение, критерии надлежащего извещения, производство по делу, способ напарвления извещения, место направления извещения, ненадлежащее извещение, административное принуждение, административное правонарушение, виды ненадлежащих извещений, судебные извещения.
\end{abstract}

Надлежащее извещение в производстве по делам об административных правонарушениях

Проблема уведомления лица, в отношении которого возбуждено производство по делу об административном правонарушении, является достаточно острой как на стадии возбуждения дела об административном правонарушении, так и на стадии его рассмотрения. Ненадлежащее извещение должностными лицами административно-юрисдикционных органов является одной из основных причин, по которой постановления о назначении административного наказания признаются судами незаконными и отменяются. Как правило, ненадлежащими извещения признаются в следующих случаях:
- извещение направлено без указания цели вызова лица в орган государственной власти, либо указание в извещении не той (ошибочной) цели вызова (например, вызов на составление протокола по другому факту правонарушения ${ }^{1}$;

\footnotetext{
1 Постановление Федерального арбитражного суда Волго-Вятского округа от 12.01.2006 № А82-4488/2005-31. Досутп из справоч.-правов.системы «Консультант Плюс»; Постановление Двенадцатого арбитражного апелляционного суда от 13.01.2012 по делу № А12-11381/2011; Постановление Федерального арбитражного суда Северо-Кавказского округа от 30.03.2010 по делу № А32-39211/2009-51/735-216АЖ; Постановление Федерального арбитражного суда СевероКавказского округа от 20.04.2009 по делу № А32-17671/20083/304-59АЖ; Постановление Седьмого арбитражного апел-
} 
- извещение вручено лицу, которое не уполномочено лицом, привлекаемым к ответственности, на представление его интересов (лицо, имеющее общую доверенность, выданную до возбуждения производства по делу, не содержащую полномочия на представление интересов при решении вопросов о возбуждении производства по делу об административном правонарушении по конкретному факту нарушения), или лицу, не уполномоченному на получение корреспонденции ${ }^{2}$;

- $\quad$ извещение направлено незаблаговременно - в сроки, не позволяющие лицу, получившему такое извещение, явиться в назначенное время

ляционного суда от 04.03.2013 по делу № А03-17695/2012; Постановление Девятого арбитражного апелляционного суда от 15.01.2010 № 09АП-26296/2009-АК по делу № А40109094/09-130-585; Постановление Пятнадцатого арбитражного апелляционного суда от 07.08.2009 № 15АП-5166/2009 по делу № А32-6770/2009; Постановление Восемнадцатого арбитражного апелляционного суда от 10.12.2013 г. № 18АП12316/2013 по делу № А07-14405/2013; Постановление Девятнадцатого арбитражного апелляционного суда от 24.07.2013 по делу № А35-12881/2012 // Картотека арбитражных дел. URL: http://kad.arbitr.ru (дата обращения: 04.08.2014).

2 Решение Санкт-Петербургского городского суда от 10.02.2011 № 12-80. Доступ из справоч.-правов.системы «Консультант Плюс»; Постановление Федерального арбитражного суда Северо-Западного округа от 07.02.2011 по делу № А21-5066/2010; Постановление Второго арбитражного апелляционного суда от 10.07.2014 по делу № А17-6868/2013; Постановление Шестого арбитражного апелляционного суда от 30.04.2013 № 06АП-1488/2013 по делу № А $37-3811 / 2012$; Постановление Седьмого арбитражного апелляционного суда от 04.04.2013 по делу № А27-20679/2012; Постановление Двенадцатого арбитражного апелляционного суда от 24.01.2013 по делу № А57-17820/2012; Постановление Пятнадцатого арбитражного апелляционного суда от 23.12.2011 № 15АП-13056/2011 по делу № А53-13173/2011; Решение Арбитражного суда Московской области от 20.10.2009 по делу № А41-26666/09; Постановление Девятого арбитражного апелляционного суда от 29.09.2008 № 09АП-9669/2008-АК по делу № А40-24011/08-146-277; Постановление Четвертого арбитражного апелляционного суда от 18.05.2011 по делу № А58-169/2011; Постановление Четвертого арбитражного апелляционного суда от 08.07.2009 по делу № А58-2314/08; Постановление Пятого арбитражного апелляционного суда от 19.10.2009 № 05АП-4762/2009 по делу № А59-3314/2009; Постановление Седьмого арбитражного апелляционного суда от 18.06.2010 № 07АП-4696/10 по делу № А27-4028/2010; Постановление Тринадцатого арбитражного апелляционного суда от 02.06.2009 по делу № А56-60059/2008; Постановление ФАС Центрального округа от 26.10.2009 по делу № А62-4434/2009; Постановление ФАС Северо-Кавказского округа от 17.12.2010 по делу № A18-372/2010 // Картотека арбитражных дел. URL: http://kad.arbitr.ru (дата обращения: 04.08.2014). и место ввиду нехватки времени (например, лицо находится в пределах юрисдикции территориального органа, но на большом расстоянии от него - в другом городе) ${ }^{3}$;

- извещение направлено исключительно посредством информационно-телекоммуникационных систем при отсутствии достоверной информации о принадлежности номеров телефонов, факсов, адреса электронной почты лицу, которому адресовано извещение ${ }^{4}$;

3 Постановление Восьмого арбитражного апелляционного суда от 15.10.2010 по делу № А81-2444/2010; Постановление Восьмого арбитражного апелляционного суда от 17.04.2014 № 08АП-1344/2014 по делу № А81-4266/2013, Постановление Восьмого арбитражного апелляционного суда от 28.01.2014 по делу № А75-6813/2013; Постановление Двенадцатого арбитражного апелляционного суда от 19.03.2009 по делу № А12-987/2009; Постановление Федерального арбитражного суда Поволжского округа от 30.06.2009 по делу № А12-987/2009; Постановление Семнадцатого арбитражного апелляционного суда от 08.10.2012 № 17АП-10429/2012-АК по делу № А6028934/2012// Картотека арбитражных дел. URL: http:// kad.arbitr.ru (дата обращения: 04.08.2014); Постановление Семнадцатого арбитражного апелляционного суда от 26.10.2011 № 17АП-9646/2011-АК по делу № А50П605/2011. Досутп из справоч.-правов.системы «Консультант Плюс».

4 Решение Нижегородского областного суда от 07.02.2011 по делу № 7-37/11. Досутп из справоч.-правов.системы «Консультант Плюс»; Постановление Седьмого арбитражного апелляционного суда от 04.03.2013 по делу № А03-17695/2012; Постановление Федерального арбитражного суда Волго-Вятского округа от 07.11.2013 по делу № А29-38/2013; Постановление Федерального арбитражного суда Волго-Вятского округа от 14.12.2012 по делу № А 82 4028/2012; Постановление Федерального арбитражного суда Восточно-Сибирского округа от 24.02.2010 по делу № A10-4035/2009; Постановление Федерального арбитражного суда Северо-Западного округа от 17.09.2009 по делу № А56-11689/2009; Постановление Федерального арбитражного суда Уральского округа от 15.07.2009 № Ф094913/09-С1 по делу № А76-2428/2009-56-178; Постановление Восьмого арбитражного апелляционного суда от 10.04.2014 № 08АП-648/2014 по делу № А46-13861/2013; Постановление Тринадцатого арбитражного апелляционного суда от 09.07.2014 по делу № А26-9077/2013; Постановление Пятнадцатого арбитражного апелляционного суда от 15.11.2013 № 15АП-17775/2013 по делу № А53-14557/2013; Постановление Шестнадцатого арбитражного апелляционного суда от 12.09.2013 по делу № А63-3531/2013// Картотека арбитражных дел. URL: http://kad.arbitr.ru (дата обращения: 04.08.2014); Постановление Семнадцатого арбитражного апелляционного суда от 05.04.2012 № 17АП2212/2012-АК по делу № А71-17312/2011. Досутп из справоч.-правов.системы «Консультант Плюс». 
- ненаправление извещения вообще ${ }^{5}$, что в настоящее время встречается достаточно редко. Также правила об извещении лица считаются нарушенными в случаях, если:

- процессуальное значимое действие (составление протокола об административном правонарушении, рассмотрение дела об административном правонарушении) совершено при отсутствии сведений о вручении извещения при его направлении ${ }^{6}$;

- процессуальный документ (протокол об административном правонарушении) составлен не в день, который указан в извещении о времени и месте его составления, и в отсутствие лица, в отношении которого он составляется ${ }^{7}$.

Наличие подобных нарушений, на наш взгляд, обусловлено отсутствием в действующем законодательстве четких критериев, позволяющих определить, какое извещение является надлежащим, а какое нет.

До недавнего времени в КоАП РФ не было установлено даже требований к тому, как следует извещать лиц, участвующих в производстве по делу об административном правонарушении. Федеральным законом от 6 декабря 2011 г. № 404-Ф3 «0 внесении изменений в Кодекс Российской Федерации об административных правонарушениях» 8 была введена статья 25.15, устанавливающая, как необходимо извещать участников дела об ад-

\footnotetext{
5 Постановление Девятого арбитражного апелляционного суда от 09.10.2007 № 09АП-13126/07-АК по делу № А406681/07-122-61; Постановление Двенадцатого арбитражного апелляционного суда от 29.03.2013 по делу № А12-27612/12; Постановление Двенадцатого арбитражного апелляционного суда от 01.02.2013 по делу № А12-22802/2012; Постановление Второго арбитражного апелляционного суда от 24.09.2013 по делу № А28-2949/2013; Постановление Девятого арбитражного апелляционного суда от 23.06.2014 № 09АП-17809/2014 по делу № А40-181674/2013 // Картотека арбитражных дел. URL: http://kad.arbitr.ru (дата обращения: 04.08.2014)

6 Решение Арбитражного суда Свердловской области от 20.03.2009 по делу № А60-5061/2009-С9; Постановление Восьмого арбитражного апелляционного суда от 07.10.2010 по делу № A81-2442/2010 // Картотека арбитражных дел. URL: http://kad.arbitr.ru (дата обращения: 04.08.2014).

7 Постановление ФАС Северо-Кавказского округа от 10.11.2010 по делу № A18-369/2010 // Картотека арбитражных дел. URL: http://kad.arbitr.ru (дата обращения: 04.08.2014).

8 Федеральный закон от 06.12.2011 № 404-Ф3 «О внесении изменений в Кодекс Российской Федерации об административных правонарушениях» // Российская газета. - 2011. - 10 декабря.
}

министративном правонарушении и куда направлять корреспонденцию. Так, в соответствии с ч. 1 ст. 25.15 КоАП РФ органы административной юрисдикции обязаны извещать и вызывать участников дела заказным письмом с уведомлением о вручении, повесткой с уведомлением о вручении, телефонограммой или телеграммой, по факсимильной связи либо с использованием иных средств связи и доставки, обеспечивающих фиксирование извещения или вызова и вручение его адресату. Согласно частям 2, 3, 4 указанной статьи, извещения направляются по месту жительства, если участником дела является гражданин, и по месту нахождения юридического лица, его филиала или представительства, если участником дела является юридическое лицо. Если юридическое лицо, участвующее в производстве по делу об административном правонарушении, ведет дело через представителя, то извещение направляется также по месту нахождения (месту жительства) представителя. Если лицо, участвующее в производстве по делу об административном правонарушении, заявило ходатайство о направлении извещений по иному адресу, то суд, орган или должностное лицо, в производстве которых находится дело, направляет извещение также по этому адресу. В таком случае извещение считается врученным лицу, участвующему в производстве по делу об административном правонарушении, если извещение доставлено по указанному адресу.

Таким образом, в ст. 25.15 КоАП РФ в качестве критериев надлежащего извещения установлены способ и место его направления. Вместе с тем, даже наличие указанных критериев не позволяет определить, что делать, если извещение направлено так, как указано в статье КоАП РФ, но уведомление о вручении извещения органом административной юрисдикции к моменту совершения процессуальнозначимого действия не получено либо извещение адресату не было вручено, о чем орган почтовой связи уведомил административный орган. Отсутствие законодательно установленного алгоритма последующих действий должностных лиц в таких ситуациях приводит к совершению большинства ошибок. Устранить данный пробел можно, указав в законе случаи, позволяющие считать извещение надлежащим при его фактическом неполучении, то есть критерии надлежащего извещения.

Подобные критерии установлены, например, для судебных извещений в гражданском и арбитражном процессе. Так, в соответствии со ст. 123 АПК РФ гражданин считается извещенным надлежащим образом, если судебное извещение вручено ему лич- 
но или совершеннолетнему лицу, проживающему совместно с этим гражданином, под расписку на подлежащем возврату в арбитражный суд уведомлении о вручении либо ином документе с указанием даты и времени вручения, а также источника информации. Судебное извещение, адресованное юридическому лицу, вручается лицу, уполномоченному на получение корреспонденции. Лица, участвующие в деле, и иные участники арбитражного процесса также считаются извещенными надлежащим образом арбитражным судом, если: 1) адресат отказался от получения копии судебного акта и этот отказ зафиксирован организацией почтовой связи или арбитражным судом; 2) несмотря на почтовое извещение, адресат не явился за получением копии судебного акта, направленной арбитражным судом в установленном порядке, о чем организация почтовой связи уведомила арбитражный суд; 3) копия судебного акта не вручена в связи с отсутствием адресата по указанному адресу, о чем организация почтовой связи уведомила арбитражный суд с указанием источника данной информации; 4) судебное извещение вручено уполномоченному лицу филиала или представительства юридического лица; 5) судебное извещение вручено представителю лица, участвующего в деле; 6) имеются доказательства вручения или направления судебного извещения в порядке, установленном ч.ч. 2 и 3 ст. 122 АПК РФ. Если место нахождения или место жительства ответчика неизвестно, то надлежащим извещением считается направление извещения по последнему известному месту нахождения или месту жительства ответчика.
Анализ судебно-арбитражной практики свидетельствует о том, что критерии, установленные для судебных извещений, применяются арбитражными судами для оценки качества извещений, направляемых административными органами в рамках производства по делам об административных правонарушениях 9 . Вместе с тем, применение указанных подходов является обязательным лишь для судов. В связи с этим органы исполнительной власти, зачастую не имея четких представлений о том, могут ли они совершить процессуальное действие, совершая его, нарушают права лиц, участвующих в производстве по делу об административном правонарушении. Следствием таких нарушений становится незаконность вынесенных постановлений.

Полагаем, что в КоАП РФ должны быть определены такие же требования к извещениям, как в гражданском и арбитражном процессе. Их нормативное установление создаст предпосылки для исключения нарушений прав граждан при извещении. Кроме того, наличие таких критериев, на наш взгляд, будет способствовать соблюдению принципа неотвратимости ответственности, поскольку позволит сократить количество случаев, при которых лицо, злоупотребляя правом и уклоняясь от получения извещения, пытается избежать административной ответственности. Установление требований к надлежащему извещению облегчит работу контролирующих органов, поскольку эти критерии станут определенным стандартом, на соответствие которому будут оцениваться действия должностных лиц.

\section{Библиография:}

1. Постановление Двенадцатого арбитражного апелляционного суда от 13.01 .2012 по делу № A12-11381/2011 // Картотека арбитражных дел. URL: http://kad.arbitr.ru (дата обращения: 04.08.2014).

2. Постановление Федерального арбитражного суда Волго-Вятского округа от 12.01.2006 № A82-4488/2005-31. Досутп из справоч.-правов.системы «Консультант Плюс».

3. Постановление Федерального арбитражного суда Северо-Кавказского округа от 30.03 .2010 по делу № A32-39211/2009-51/735-216АЖ // Картотека арбитражных дел. URL: http://kad.arbitr.ru (дата обращения: 04.08.2014).

4. Постановление Федерального арбитражного суда Северо-Кавказского округа от 20.04.2009 по делу № А3217671/2008-3/304-59АЖ // Картотека арбитражных дел. URL: http://kad.arbitr.ru (дата обращения: 04.08.2014).

5. Постановление Седьмого арбитражного апелляционного суда от 04.03.2013 по делу № A03-17695/2012 // Картотека арбитражных дел. URL: http://kad.arbitr.ru (дата обращения: 04.08.2014).

\footnotetext{
9 См., напр.: постановление Четвертого арбитражного апелляционного суда от 18.05.2011 по делу № А58-169/2011; постановление Седьмого арбитражного апелляционного суда от 07.04.2011 № 07АП-1792/10 по делу № А03-13250/2010 // Картотека арбитражных дел. URL: http://kad.arbitr.ru (дата обращения: 04.08.2014).
} 
Административное и муниципальное право 2 (86) 2015

6. Постановление Девятого арбитражного апелляционного суда от 15.01.2010 № 09АП-26296/2009-АК по делу № A40-109094/09-130-585 // Картотека арбитражных дел. URL: http://kad.arbitr.ru (дата обращения: 04.08.2014).

7. Постановление Пятнадцатого арбитражного апелляционного суда от 07.08.2009 № 15AП-5166/2009 по делу № A32-6770/2009 // Картотека арбитражных дел. URL: http://kad.arbitr.ru (дата обращения: 04.08.2014).

8. Постановление Восемнадцатого арбитражного апелляционного суда от 10.12.2013 г. № 18АП-12316/2013 по делу № A07-14405/2013 // Картотека арбитражных дел. URL: http://kad.arbitr.ru (дата обращения: 04.08.2014).

9. Постановление Девятнадцатого арбитражного апелляционного суда от 24.07.2013 по делу № А35-12881/2012 // Картотека арбитражных дел. URL: http://kad.arbitr.ru (дата обращения: 04.08.2014).

10. Решение Санкт-Петербургского городского суда от 10.02.2011 № 12-80. Досутп из справоч.-правов.системы «Консультант Плюс».

11. Постановление Федерального арбитражного суда Северо-Западного округа от 07.02.2011 по делу № А215066/2010 // Картотека арбитражных дел. URL: http://kad.arbitr.ru (дата обращения: 04.08.2014).

12. Постановление Второго арбитражного апелляционного суда от 10.07.2014 по делу № А17-6868/2013 // Картотека арбитражных дел. URL: http://kad.arbitr.ru (дата обращения: 04.08.2014).

13. Постановление Шестого арбитражного апелляционного суда от 30.04.2013 № 06АП-1488/2013 по делу № А373811/2012 // Картотека арбитражных дел. URL: http://kad.arbitr.ru (дата обращения: 04.08.2014).

14. Постановление Седьмого арбитражного апелляционного суда от 04.04.2013 по делу № A27-20679/2012 // Картотека арбитражных дел. URL: http://kad.arbitr.ru (дата обращения: 04.08.2014).

15. Постановление Двенадцатого арбитражного апелляционного суда от 24.01.2013 по делу № A57-17820/2012 // Картотека арбитражных дел. URL: http://kad.arbitr.ru (дата обращения: 04.08.2014).

16. Постановление Пятнадцатого арбитражного апелляционного суда от 23.12.2011 № 15АП-13056/2011 по делу № A53-13173/2011 // Картотека арбитражных дел. URL: http://kad.arbitr.ru (дата обращения: 04.08.2014).

17. Решение Арбитражного суда Московской области от 20.10.2009 по делу № А41-26666/09 // Картотека арбитражных дел. URL: http://kad.arbitr.ru (дата обращения: 04.08.2014).

18. Постановление Девятого арбитражного апелляционного суда от 29.09.2008 № 09АП-9669/2008-АК по делу № A40-24011/08-146-277 // Картотека арбитражных дел. URL: http://kad.arbitr.ru (дата обращения: 04.08.2014).

19. Постановление Четвертого арбитражного апелляционного суда от 18.05.2011 по делу № A58-169/2011 // Картотека арбитражных дел. URL: http://kad.arbitr.ru (дата обращения: 04.08.2014).

20. Постановление Четвертого арбитражного апелляционного суда от 08.07.2009 по делу № A58-2314/08 // Картотека арбитражных дел. URL: http://kad.arbitr.ru (дата обращения: 04.08.2014).

21. Постановление Пятого арбитражного апелляционного суда от 19.10.2009 № 05АП-4762/2009 по делу № А593314/2009 // Картотека арбитражных дел. URL: http://kad.arbitr.ru (дата обращения: 04.08.2014).

22. Постановление Седьмого арбитражного апелляционного суда от 18.06.2010 № 07АП-4696/10 по делу № А274028/2010 // Картотека арбитражных дел. URL: http://kad.arbitr.ru (дата обращения: 04.08.2014).

23. Постановление Тринадцатого арбитражного апелляционного суда от 02.06.2009 по делу № A56-60059/2008 // Картотека арбитражных дел. URL: http://kad.arbitr.ru (дата обращения: 04.08.2014).

24. Постановление ФАС Центрального округа от 26.10.2009 по делу № A62-4434/2009 // Картотека арбитражных дел. URL: http://kad.arbitr.ru (дата обращения: 04.08.2014).

25. Постановление ФАС Северо-Кавказского округа от 17.12.2010 по делу № A18-372/2010 // Картотека арбитражных дел. URL: http://kad.arbitr.ru (дата обращения: 04.08.2014).

26. Постановление Восьмого арбитражного апелляционного суда от 15.10.2010 по делу № А81-2444/2010 // Картотека арбитражных дел. URL: http://kad.arbitr.ru (дата обращения: 04.08.2014).

27. Постановление Восьмого арбитражного апелляционного суда от 17.04.2014 № 08АП-1344/2014 по делу № А814266/2013 // Картотека арбитражных дел. URL: http://kad.arbitr.ru (дата обращения: 04.08.2014).

28. Постановление Восьмого арбитражного апелляционного суда от 28.01.2014 по делу № A75-6813/2013 // Картотека арбитражных дел. URL: http://kad.arbitr.ru (дата обращения: 04.08.2014).

29. Постановление Двенадцатого арбитражного апелляционного суда от 19.03 .2009 по делу № A12-987/2009 // Картотека арбитражных дел. URL: http://kad.arbitr.ru (дата обращения: 04.08.2014).

30. Постановление Федерального арбитражного суда Поволжского округа от 30.06.2009 по делу № A12-987/2009 // Картотека арбитражных дел. URL: http://kad.arbitr.ru (дата обращения: 04.08.2014).

31. Постановление Семнадцатого арбитражного апелляционного суда от 08.10.2012 № 17АП-10429/2012-АК по делу № A60-28934/2012 // Картотека арбитражных дел. URL: http://kad.arbitr.ru (дата обращения: 04.08.2014).

32. Постановление Семнадцатого арбитражного апелляционного суда от 26.10.2011 № 17АП-9646/2011-АК по делу № А50П-605/2011. Досутп из справоч.-правов.системы «Консультант Плюс».

33. Решение Нижегородского областного суда от 07.02.2011 по делу № 7-37/11. Досутп из справоч.-правов.системы «Консультант Плюс».

34. Постановление Федерального арбитражного суда Волго-Вятского округа от 07.11.2013 по делу № A29-38/2013 // Картотека арбитражных дел. URL: http://kad.arbitr.ru (дата обращения: 04.08.2014).

35. Постановление Федерального арбитражного суда Волго-Вятского округа от 14.12.2012 по делу № A82-4028/2012 // Картотека арбитражных дел. URL: http://kad.arbitr.ru (дата обращения: 04.08.2014). 
36. Постановление Федерального арбитражного суда Восточно-Сибирского округа от 24.02.2010 по делу № А104035/2009 // Картотека арбитражных дел. URL: http://kad.arbitr.ru (дата обращения: 04.08.2014).

37. Постановление Федерального арбитражного суда Северо-Западного округа от 17.09.2009 по делу № А5611689/2009 // Картотека арбитражных дел. URL: http://kad.arbitr.ru (дата обращения: 04.08.2014).

38. Постановление Федерального арбитражного суда Уральского округа от 15.07.2009 № Ф09-4913/09-С1 по делу № A76-2428/2009-56-178 // Картотека арбитражных дел. URL: http://kad.arbitr.ru (дата обращения: 04.08.2014).

39. Постановление Восьмого арбитражного апелляционного суда от 10.04.2014 № 08АП-648/2014 по делу № А4613861/2013 // Картотека арбитражных дел. URL: http://kad.arbitr.ru (дата обращения: 04.08.2014).

40. Постановление Тринадцатого арбитражного апелляционного суда от 09.07.2014 по делу № A26-9077/2013 // Картотека арбитражных дел. URL: http://kad.arbitr.ru (дата обращения: 04.08.2014).

41. Постановление Пятнадцатого арбитражного апелляционного суда от 15.11.2013 № 15AП-17775/2013 по делу № A53-14557/2013 // Картотека арбитражных дел. URL: http://kad.arbitr.ru (дата обращения: 04.08.2014).

42. Постановление Шестнадцатого арбитражного апелляционного суда от 12.09 .2013 по делу № A63-3531/2013 // Картотека арбитражных дел. URL: http://kad.arbitr.ru (дата обращения: 04.08.2014).

43. Постановление Семнадцатого арбитражного апелляционного суда от 05.04.2012 № 17АП-2212/2012-АК по делу № A71-17312/2011. Досутп из справоч.-правов.системы «Консультант Плюс».

44. Постановление Девятого арбитражного апелляционного суда от 09.10.2007 № 09АП-13126/07-АК по делу № A40-6681/07-122-61 // Картотека арбитражных дел. URL: http://kad.arbitr.ru (дата обращения: 04.08.2014).

45. Постановление Двенадцатого арбитражного апелляционного суда от 29.03.2013 по делу № A12-27612/12 // Картотека арбитражных дел. URL: http://kad.arbitr.ru (дата обращения: 04.08.2014).

46. Постановление Двенадцатого арбитражного апелляционного суда от 01.02.2013 по делу № A12-22802/2012 // Картотека арбитражных дел. URL: http://kad.arbitr.ru (дата обращения: 04.08.2014).

47. Постановление Второго арбитражного апелляционного суда от 24.09.2013 по делу № А28-2949/2013 // Картотека арбитражных дел. URL: http://kad.arbitr.ru (дата обращения: 04.08.2014).

48. Постановление Девятого арбитражного апелляционного суда от 23.06.2014 № 09АП-17809/2014 по делу № А40181674/2013 // Картотека арбитражных дел. URL: http://kad.arbitr.ru (дата обращения: 04.08.2014).

49. Решение Арбитражного суда Свердловской области от 20.03.2009 по делу № А60-5061/2009-С9 Картотека арбитражных дел. URL: http://kad.arbitr.ru (дата обращения: 04.08.2014).

50. Постановление Восьмого арбитражного апелляционного суда от 07.10.2010 по делу № A81-2442/2010 // Картотека арбитражных дел. URL: http://kad.arbitr.ru (дата обращения: 04.08.2014).

51. Постановление ФАС Северо-Кавказского округа от 10.11.2010 по делу № A18-369/2010 // Картотека арбитражных дел. URL: http://kad.arbitr.ru (дата обращения: 04.08.2014).

52. Федеральный закон от 06.12.2011 № 404-Ф3 «0 внесении изменений в Кодекс Российской Федерации об административных правонарушениях» // Российская газета.-2011.-10 декабря.

53. Постановление Седьмого арбитражного апелляционного суда от 07.04.2011 № 07АП-1792/10 по делу № А0313250/2010 // Картотека арбитражных дел. URL: http://kad.arbitr.ru (дата обращения: 04.08.2014)

\section{References (transliterated):}

1. Postanovlenie Dvenadtsatogo arbitrazhnogo apellyatsionnogo suda ot 13.01 .2012 po delu № A12-11381/2011 // Kartoteka arbitrazhnykh del. URL: http://kad.arbitr.ru (data obrashcheniya: 04.08.2014).

2. Postanovlenie Federal'nogo arbitrazhnogo suda Volgo-Vyatskogo okruga ot 12.01.2006 № A82-4488/2005-31. Dosutp iz spravoch.-pravov.sistemy «Konsul'tant Plyus».

3. Postanovlenie Federal'nogo arbitrazhnogo suda Severo-Kavkazskogo okruga ot 30.03.2010 po delu № A32-39211/200951/735-216AZh // Kartoteka arbitrazhnykh del. URL: http://kad.arbitr.ru (data obrashcheniya: 04.08.2014).

4. Postanovlenie Federal'nogo arbitrazhnogo suda Severo-Kavkazskogo okruga ot 20.04.2009 po delu № A32-17671/20083/304-59AZh // Kartoteka arbitrazhnykh del. URL: http://kad.arbitr.ru (data obrashcheniya: 04.08.2014).

5. Postanovlenie Sed'mogo arbitrazhnogo apellyatsionnogo suda ot 04.03.2013 po delu № A03-17695/2012 // Kartoteka arbitrazhnykh del. URL: http://kad.arbitr.ru (data obrashcheniya: 04.08.2014).

6. Postanovlenie Devyatogo arbitrazhnogo apellyatsionnogo suda ot 15.01.2010 № 09AP-26296/2009-AK po delu № A40109094/09-130-585 // Kartoteka arbitrazhnykh del. URL: http://kad.arbitr.ru (data obrashcheniya: 04.08.2014).

7. Postanovlenie Pyatnadtsatogo arbitrazhnogo apellyatsionnogo suda ot 07.08.2009 № 15AP-5166/2009 po delu № A326770/2009 // Kartoteka arbitrazhnykh del. URL: http://kad.arbitr.ru (data obrashcheniya: 04.08.2014).

8. Postanovlenie Vosemnadtsatogo arbitrazhnogo apellyatsionnogo suda ot 10.12.2013 g. № 18AP-12316/2013 po delu № A07-14405/2013 // Kartoteka arbitrazhnykh del. URL: http://kad.arbitr.ru (data obrashcheniya: 04.08.2014).

9. Postanovlenie Devyatnadtsatogo arbitrazhnogo apellyatsionnogo suda ot 24.07.2013 po delu № A35-12881/2012 // Kartoteka arbitrazhnykh del. URL: http://kad.arbitr.ru (data obrashcheniya: 04.08.2014).

10. Reshenie Sankt-Peterburgskogo gorodskogo suda ot 10.02.2011 № 12-80. Dosutp iz spravoch.-pravov.sistemy «Konsul'tant Plyus».

11. Postanovlenie Federal'nogo arbitrazhnogo suda Severo-Zapadnogo okruga ot 07.02.2011 po delu № A21-5066/2010 // Kartoteka arbitrazhnykh del. URL: http://kad.arbitr.ru (data obrashcheniya: 04.08.2014). 
Административное и муниципальное право 2 (86) 2015

12. Postanovlenie Vtorogo arbitrazhnogo apellyatsionnogo suda ot 10.07.2014 po delu № A17-6868/2013 // Kartoteka arbitrazhnykh del. URL: http://kad.arbitr.ru (data obrashcheniya: 04.08.2014).

13. Postanovlenie Shestogo arbitrazhnogo apellyatsionnogo suda ot 30.04.2013 № 06AP-1488/2013 po delu № A373811/2012 // Kartoteka arbitrazhnykh del. URL: http://kad.arbitr.ru (data obrashcheniya: 04.08.2014).

14. Postanovlenie Sed'mogo arbitrazhnogo apellyatsionnogo suda ot 04.04.2013 po delu № A27-20679/2012 // Kartoteka arbitrazhnykh del. URL: http://kad.arbitr.ru (data obrashcheniya: 04.08.2014).

15. Postanovlenie Dvenadtsatogo arbitrazhnogo apellyatsionnogo suda ot 24.01.2013 po delu № A57-17820/2012 // Kartoteka arbitrazhnykh del. URL: http://kad.arbitr.ru (data obrashcheniya: 04.08.2014).

16. Postanovlenie Pyatnadtsatogo arbitrazhnogo apellyatsionnogo suda ot 23.12.2011 № 15AP-13056/2011 po delu № A5313173/2011 // Kartoteka arbitrazhnykh del. URL: http://kad.arbitr.ru (data obrashcheniya: 04.08.2014).

17. Reshenie Arbitrazhnogo suda Moskovskoi oblasti ot 20.10.2009 po delu № A41-26666/09 // Kartoteka arbitrazhnykh del. URL: http://kad.arbitr.ru (data obrashcheniya: 04.08.2014).

18. Postanovlenie Devyatogo arbitrazhnogo apellyatsionnogo suda ot 29.09.2008 № 09AP-9669/2008-AK po delu № A4024011/08-146-277 // Kartoteka arbitrazhnykh del. URL: http://kad.arbitr.ru (data obrashcheniya: 04.08.2014).

19. Postanovlenie Chetvertogo arbitrazhnogo apellyatsionnogo suda ot 18.05.2011 po delu № A58-169/2011// Kartoteka arbitrazhnykh del. URL: http://kad.arbitr.ru (data obrashcheniya: 04.08.2014).

20. Postanovlenie Chetvertogo arbitrazhnogo apellyatsionnogo suda ot 08.07.2009 po delu № A58-2314/08 // Kartoteka arbitrazhnykh del. URL: http://kad.arbitr.ru (data obrashcheniya: 04.08.2014).

21. Postanovlenie Pyatogo arbitrazhnogo apellyatsionnogo suda ot 19.10.2009 № 05AP-4762/2009 po delu № A593314/2009 // Kartoteka arbitrazhnykh del. URL: http://kad.arbitr.ru (data obrashcheniya: 04.08.2014).

22. Postanovlenie Sed'mogo arbitrazhnogo apellyatsionnogo suda ot 18.06.2010 № 07AP-4696/10 po delu № A274028/2010 // Kartoteka arbitrazhnykh del. URL: http://kad.arbitr.ru (data obrashcheniya: 04.08.2014).

23. Postanovlenie Trinadtsatogo arbitrazhnogo apellyatsionnogo suda ot 02.06.2009 po delu № A56-60059/2008 // Kartoteka arbitrazhnykh del. URL: http://kad.arbitr.ru (data obrashcheniya: 04.08.2014).

24. Postanovlenie FAS Tsentral'nogo okruga ot 26.10.2009 po delu № A62-4434/2009 // Kartoteka arbitrazhnykh del. URL: http://kad.arbitr.ru (data obrashcheniya: 04.08.2014).

25. Postanovlenie FAS Severo-Kavkazskogo okruga ot 17.12.2010 po delu № A18-372/2010 // Kartoteka arbitrazhnykh del. URL: http://kad.arbitr.ru (data obrashcheniya: 04.08.2014).

26. Postanovlenie Vos'mogo arbitrazhnogo apellyatsionnogo suda ot 15.10.2010 po delu № A81-2444/2010 // Kartoteka arbitrazhnykh del. URL: http://kad.arbitr.ru (data obrashcheniya: 04.08.2014).

27. Postanovlenie Vos'mogo arbitrazhnogo apellyatsionnogo suda ot 17.04.2014 № 08AP-1344/2014 po delu № A814266/2013 // Kartoteka arbitrazhnykh del. URL: http://kad.arbitr.ru (data obrashcheniya: 04.08.2014).

28. Postanovlenie Vos'mogo arbitrazhnogo apellyatsionnogo suda ot 28.01.2014 po delu № A75-6813/2013 // Kartoteka arbitrazhnykh del. URL: http://kad.arbitr.ru (data obrashcheniya: 04.08.2014).

29. Postanovlenie Dvenadtsatogo arbitrazhnogo apellyatsionnogo suda ot 19.03.2009 po delu № A12-987/2009 // Kartoteka arbitrazhnykh del. URL: http://kad.arbitr.ru (data obrashcheniya: 04.08.2014).

30. Postanovlenie Federal'nogo arbitrazhnogo suda Povolzhskogo okruga ot 30.06.2009 po delu № A12-987/2009 // Kartoteka arbitrazhnykh del. URL: http://kad.arbitr.ru (data obrashcheniya: 04.08.2014).

31. Postanovlenie Semnadtsatogo arbitrazhnogo apellyatsionnogo suda ot 08.10.2012 № 17AP-10429/2012-AK po delu № A60-28934/2012 // Kartoteka arbitrazhnykh del. URL: http://kad.arbitr.ru (data obrashcheniya: 04.08.2014).

32. Postanovlenie Semnadtsatogo arbitrazhnogo apellyatsionnogo suda ot 26.10.2011 № 17AP-9646/2011-AK po delu № A50P-605/2011. Dosutp iz spravoch.-pravov.sistemy «Konsul'tant Plyus».

33. Reshenie Nizhegorodskogo oblastnogo suda ot 07.02.2011 po delu № 7-37/11. Dosutp iz spravoch.-pravov.sistemy «Konsul'tant Plyus».

34. Postanovlenie Federal'nogo arbitrazhnogo suda Volgo-Vyatskogo okruga ot 07.11.2013 po delu № A29-38/2013 // Kartoteka arbitrazhnykh del. URL: http://kad.arbitr.ru (data obrashcheniya: 04.08.2014).

35. Postanovlenie Federal'nogo arbitrazhnogo suda Volgo-Vyatskogo okruga ot 14.12.2012 po delu № A82-4028/2012 // Kartoteka arbitrazhnykh del. URL: http://kad.arbitr.ru (data obrashcheniya: 04.08.2014).

36. Postanovlenie Federal'nogo arbitrazhnogo suda Vostochno-Sibirskogo okruga ot 24.02.2010 po delu № A10-4035/2009 // Kartoteka arbitrazhnykh del. URL: http://kad.arbitr.ru (data obrashcheniya: 04.08.2014).

37. Postanovlenie Federal'nogo arbitrazhnogo suda Severo-Zapadnogo okruga ot 17.09.2009 po delu № A56-11689/2009 // Kartoteka arbitrazhnykh del. URL: http://kad.arbitr.ru (data obrashcheniya: 04.08.2014).

38. Postanovlenie Federal'nogo arbitrazhnogo suda Ural'skogo okruga ot 15.07.2009 № F09-4913/09-S1 po delu № A762428/2009-56-178 // Kartoteka arbitrazhnykh del. URL: http://kad.arbitr.ru (data obrashcheniya: 04.08.2014).

39. Postanovlenie Vos'mogo arbitrazhnogo apellyatsionnogo suda ot 10.04.2014 № 08AP-648/2014 po delu № A4613861/2013 // Kartoteka arbitrazhnykh del. URL: http://kad.arbitr.ru (data obrashcheniya: 04.08.2014).

40. Postanovlenie Trinadtsatogo arbitrazhnogo apellyatsionnogo suda ot 09.07.2014 po delu № A26-9077/2013 // Kartoteka arbitrazhnykh del. URL: http://kad.arbitr.ru (data obrashcheniya: 04.08.2014).

41. Postanovlenie Pyatnadtsatogo arbitrazhnogo apellyatsionnogo suda ot 15.11.2013 № 15AP-17775/2013 po delu № A5314557/2013 // Kartoteka arbitrazhnykh del. URL: http://kad.arbitr.ru (data obrashcheniya: 04.08.2014). 


\section{Административная и муниципальная ответственность}

42. Postanovlenie Shestnadtsatogo arbitrazhnogo apellyatsionnogo suda ot 12.09 .2013 po delu № A63-3531/2013 // Kartoteka arbitrazhnykh del. URL: http://kad.arbitr.ru (data obrashcheniya: 04.08.2014).

43. Postanovlenie Semnadtsatogo arbitrazhnogo apellyatsionnogo suda ot 05.04.2012 № 17AP-2212/2012-AK po delu № A71-17312/2011. Dosutp iz spravoch.-pravov.sistemy «Konsul'tant Plyus».

44. Postanovlenie Devyatogo arbitrazhnogo apellyatsionnogo suda ot 09.10.2007 № 09AP-13126/07-AK po delu № A406681/07-122-61 // Kartoteka arbitrazhnykh del. URL: http://kad.arbitr.ru (data obrashcheniya: 04.08.2014).

45. Postanovlenie Dvenadtsatogo arbitrazhnogo apellyatsionnogo suda ot 29.03.2013 po delu № A12-27612/12 // Kartoteka arbitrazhnykh del. URL: http://kad.arbitr.ru (data obrashcheniya: 04.08.2014).

46. Postanovlenie Dvenadtsatogo arbitrazhnogo apellyatsionnogo suda ot 01.02.2013 po delu № A12-22802/2012 // Kartoteka arbitrazhnykh del. URL: http://kad.arbitr.ru (data obrashcheniya: 04.08.2014).

47. Postanovlenie Vtorogo arbitrazhnogo apellyatsionnogo suda ot 24.09.2013 po delu № A28-2949/2013 // Kartoteka arbitrazhnykh del. URL: http://kad.arbitr.ru (data obrashcheniya: 04.08.2014).

48. Postanovlenie Devyatogo arbitrazhnogo apellyatsionnogo suda ot 23.06.2014 № 09AP-17809/2014 po delu № A40181674/2013 // Kartoteka arbitrazhnykh del. URL: http://kad.arbitr.ru (data obrashcheniya: 04.08.2014).

49. Reshenie Arbitrazhnogo suda Sverdlovskoi oblasti ot 20.03.2009 po delu № A60-5061/2009-S9 Kartoteka arbitrazhnykh del. URL: http://kad.arbitr.ru (data obrashcheniya: 04.08.2014).

50. Postanovlenie Vos'mogo arbitrazhnogo apellyatsionnogo suda ot 07.10.2010 po delu № A81-2442/2010 // Kartoteka arbitrazhnykh del. URL: http://kad.arbitr.ru (data obrashcheniya: 04.08.2014).

51. Postanovlenie FAS Severo-Kavkazskogo okruga ot 10.11.2010 po delu № A18-369/2010 // Kartoteka arbitrazhnykh del. URL: http://kad.arbitr.ru (data obrashcheniya: 04.08.2014).

52. Federal'nyi zakon ot 06.12.2011 № 404-FZ «0 vnesenii izmenenii v Kodeks Rossiiskoi Federatsii ob administrativnykh pravonarusheniyakh» // Rossiiskaya gazeta.-2011.-10 dekabrya.

53. Postanovlenie Sed'mogo arbitrazhnogo apellyatsionnogo suda ot 07.04.2011 № 07AP-1792/10 po delu № A0313250/2010 // Kartoteka arbitrazhnykh del. URL: http://kad.arbitr.ru (data obrashcheniya: 04.08.2014) 